\title{
Replacing Race: Interactive \\ CONSTRUCTIONISM ABOUT \\ Racialized Groups
}

\author{
ADAM HOCHMAN \\ Macquarie University
}

In this paper I defend anti-realism about race and a new theory of racialization. I argue that there are no races, only racialized groups. Many social constructionists about race have adopted racial formation theory to explain how 'races' are formed. However, anti-realists about race cannot adopt racial formation theory, because it assumes the reality of race. I introduce interactive constructionism about racialized groups as a theory of racialization for anti-realists about race. Interactive constructionism moves the discussion away from the dichotomous (social vs. biological) metaphysics that has marred this debate, and posits that racialized groups are the joint products of a broad range of non-racial factors, which interact.

Keywords: racialization, racial naturalism, social constructionism about race, antirealism about race, developmental systems theory, interactive constructionism, racialized groups

\section{Introduction}

This article introduces interactive constructionism about racialized groups, a new position in the debate about the nature and reality of race. Interactive constructionism complements anti-realism about race. It posits that race is not real, but that racialization is a real process which produces racialized groups. Interactive constructionism thus offers an alternative to realist views about race, such as racial naturalism and social constructionism about race. It captures the positive aspects of these two standard positions while avoiding their empirical and theoretical downfalls. Interactive constructionism offers a much-needed account of

Contact: Adam Hochman <adam.hochman@mq.edu.au> 
the ontology of racialized groups as entities distinct from 'races', and goes beyond the dichotomous (biological vs. social) approach that has stifled progress in the metaphysics of race.

The idea of interactive constructionism is borrowed from developmental systems theory (DST), a biological framework for understanding the processes of development, inheritance and evolution (Oyama, Griffiths, \& Gray 2001; Griffiths \& Hochman 2015). ${ }^{1}$ In the DST literature, constructive interactionism refers to the epigenetic processes by which a variety of developmental resources interact to construct the phenotype. I take the idea of constructive interactionism from DST and apply it to the companion concepts of 'racialization' and the 'racialized group'. I retitle it 'interactive constructionism' because this phrasing highlights the fact that racialized groups are the real but contingent products of human practices.

Interactive constructionism posits that the groups we call 'races' - but which I argue are really racialized groups-emerge out of the ongoing interaction between a number of factors: administrative, biological, cultural, economic, geographic, gendered, historical, lingual, phenomenological, political, psychological, religious, social, and so on. The strength of any given interactant is context-dependent. Racialization is a contingent historical fact, and groups can be deracialized over time. It happens from without, as when dominant groups racialize others, and from within, as when groups resist or embrace racial identities. Racialization comes in degrees, so groups can be more or less racialized at any historical moment (Blum 2002). Racialization also happens on the individual level, and individuals may be racialized differently in different contexts and at different points of their lives.

Contra racial naturalism, interactive constructionism rejects the view that there are human biological races. There is now widespread agreement that we are not a very genetically diverse species, that our biological traits are predominantly smooth in their distributions across geographic space, that there are no major human lineages, and that there is nothing scientifically privileged about conventional 'racial' classification (Hochman 2013a; Hunley, Cabana, \& Long 2015; Keita et al. 2004; Lewontin 1972; Serre \& Pääbo 2004; Templeton 2013). Race naturalists have thus been forced to trivialize 'race' and have conflated it with other concepts, such as 'population', in attempts to retain the category (e.g., Leroi 2005; Sesardic 2013). While human biological diversity is not well characterized as racial, the interactive constructionist does not leave biology out of the picture altogether. There are no races, but our (non-racial) biological diversity

1. While I focus on how constructive interactionism has been used in DST, the concept has a long history. Kristin Thorleifsdottir (2008) traces its origins to the work of James Baldwin (18611934), John Dewey (1859-1952), Kurt Lewin (1890-1947), Jean Piaget (1896-1980), and Lev Vygotsky (1896-1934). 
still plays a role as one of the interactants in the racialization process, because racialized groups have biological inclusion criteria, vague and arbitrary as they may be.

Interactive constructionism offers an alternative to social constructionism about race. I present both normative and metaphysical arguments against social constructionism. The normative arguments involve both academic and public understanding of 'race'. Scholars often appeal to social constructionism as an alternative to racial naturalism, but I argue that social constructionism (properly understood) cannot perform this intended role, as it is consistent with a biological ontology of race. Rather than offering an alternative to racial naturalism, social constructionism introduces a conceptual and ontological distinction between 'social race' and 'biological race'. This distinction is seldom made explicit, and this is especially problematic when it comes to public understanding of 'race'. Given the widespread assumption that 'race' is a biological category, when social constructionists write and speak about 'race' it will likely be understood by the general public as referring to 'biological race', and so there is a risk that social constructionism might play a role in legitimating racial naturalism.

Turning to a metaphysical line of critique, I present what I call a specificity argument against 'social race'. That is, I show that 'race' loses its conceptual and historical specificity when it is interpreted as a social kind. It becomes a vague and transhistorical category, which cannot be distinguished from a range of other group categories or categories of prejudice. We could conclude from this that 'social race' is something vastly different to what we might have expected. I argue that the right reaction is to abandon a social metaphysics of race. ${ }^{2}$

Race is best understood as a biological concept which fails to refer. Antirealism has been the least popular position in the debate about the nature and reality of race, because it leaves the phenomena race naturalists and social constructionists are interested in unaccounted for. Even if we reject racial naturalism, there is still some modicum of geographically structured human biological diversity. Even if we reject social constructionism, it is still an attempt to capture something very real and important, something which cannot be reduced to categories such as ethnicity, nation, or class. In order for anti-realists to address and illuminate these phenomena, anti-realism about race needs to be supplemented with realism about racialized groups. We need to be able to talk about-and to write policy about-the groups we have been calling 'races', while at the same time avoid the metaphysical mistake of reifying race. Interactive constructionism about racialized groups allows us to do this.

Interactive constructionism is not the first attempt to go beyond the mere as-

2. For other critiques of social constructionism about race, see Atkin (2012), Blum (2010), Glasgow (2006) and Mallon (2004). 
sertion of constructionism and toward a theory of the actual process of construction. Michael Omi and Howard Winant influentially describe the construction process in their book Racial Formation in the United States, now in its third edition. They define "racial formation as the sociohistorical process by which racial identities are created, lived out, transformed, and destroyed" (Omi \& Winant 2015: 109). Many social constructionists have adopted racial formation theory as a way to explain how 'races' are formed. Anti-realists cannot adopt racial formation theory, however, as it assumes the reality of race.

Interactive constructionism thus fills an important gap in the literature: it offers a theory of racialization for anti-realists about race. Interactive constructionism makes anti-realism about race appealing by offering a plausible alternative to racial ontology. It offers an inclusive interpretation of the construction process, which involves a broad range of interactants, none of which are 'racial', but which together can produce racialized groups.

In this paper I will make a case both against the reality of race and for interactive constructionism about racialized groups. My focus is on motivating and explaining interactive constructionism, not on applying the theory to case studies, which is beyond the scope of this paper. Because arguments against racial naturalism have been well-rehearsed elsewhere, I will not repeat them here (Appiah 1996; Fujimura et al. 2014; Hochman 2013c; Lewontin 1972; Templeton 2013; Yudell, Roberts, DeSalle, \& Tishkoff 2016; Zack 2002). I focus my critical attention exclusively on social constructionism about race, which is the most widely held position among philosophers of race. I will not respond directly to deflationism about race (Gannett 2010; Lemeire 2016; Ludwig 2015; Mallon 2006; McPherson 2015), as I have done so elsewhere (Hochman 2016a), and I will not respond to Quayshawn Spencer's (2014a) biological realism about 'race' as understood by the folk, for the same reason (Hochman 2014; cf. Spencer 2014b). Nor will I be responding to pragmatism about race (Gannett 2010; Kitcher 2007), or to the latest theory, 'basic racial realism' (Glasgow \& Woodward 2015). I will note here, however, that for the interactive constructionist the debate about the metaphysics does not need to be deflated because it can be solved, that the solution - that race is not real, but racialized groups are-may be the most pragmatic, and that some my arguments against social constructionism about race also apply to the 'basic racial realism' approach.

This paper is organized as follows. In Section 2 I discuss and argue against social constructionism about race. Section 3 focuses on anti-realism about race and the ideas of racialization and the racialized group. I argue that anti-realism is the right metaphysical position about race (but that it needs to be supplemented with a theory of racialization) and I defend anti-realism against some possible criticisms. In Section 4 I introduce interactive constructionism as the way to 
conceptualize the racialization process and its products, racialized groups. I also defend interactive constructionism against possible criticisms.

\section{What's Wrong with Social Constructionism about Race?}

Social constructionism about race is not a single, unified theory. Social constructionism has been understood as the view that biological race is an illusion, or is otherwise arbitrary, contingent, and conventional (Bobo 2008: x; Gannett 2010; Hochman 2013a), that biological races are literally the products of social forces (Kitcher 1999; Outlaw 1996), and that race is a real social kind (Diaz-Leon 2015; Haslanger 2012; Mills 1998; Sundstrom 2002b; Taylor 2004). Notice that these are very different theories. On the first race is a biological concept, but one without a biological referent. On the second race is a biological concept with a biological referent. On the third race is a social concept with a social referent.

I am sympathetic with Lawrence Blum when he writes that when it comes to 'race' "the language of 'social construction' seems to me too fraught with confusion to recommend" (Blum 2010: 304). While disagreement about the meaning of theoretical terms is commonplace, the breadth of disagreement about the meaning of 'social constructionism about race' means that identifying oneself as a social constructionist conveys very little. It does not convey whether one thinks of race as a biological or a social concept, or whether one believes that 'race' refers to anything in the world. That does not mean that social constructionism about race is wrong, but it does mean that without further elaboration, or until a consensus about its meaning is forged, the label is empty.

The division between racial naturalism, social constructionism, and antirealism about race is usually interpreted as metaphysical in nature (e.g., Mills 1998; Taylor 2004; Winther 2014). From this perspective, the confusion surrounding the proper definition of social constructionism could potentially be resolved. From a metaphysical standpoint, the view that biological race is a social myth is best viewed as anti-realism about biological race, rather than as social constructionism, because it amounts to the claim that biological race is not real. The view that biological races are literally constructed by social forces is best classified as a form of racial naturalism, as it is a view about how 'biological races' are created. It is only the view that race is a social kind which genuinely contrasts with both anti-realism and racial naturalism. The social kind approach is therefore the best candidate for the title of social constructionism about race. I will focus my critical attention on this view in order to motivate anti-realism about race and then interactive constructionism about racialized groups. 


\subsection{Normative Arguments against Social Constructionism}

Social constructionism is commonly interpreted as an alternative to racial naturalism. "To say that race is a social construction", writes Blum, "is at least to say that it is not a biological kind, a 'natural kind"' (2010: 304). It does appear that most scholars assume that social constructionism is incompatible with racial naturalism. However, many race naturalists endorse some version of social constructionism about race (Hardimon 2013; Kitcher 1999; Outlaw 1996; Relethford 2009; Spencer 2015). As Jeremy Pierce notes, "Someone could very easily hold that there are races that are natural kinds without denying that there are also social kinds called races" (Pierce 2014: 28). This is precisely the view that Michael Hardimon defends. "The concept socialrace makes it possible to represent the race-that-is-a-social-phenomenon as a social phenomenon", he explains. "Those who deny and those who affirm the reality of biological race can use it in good intellectual conscience" (Hardimon 2013: 26). Social constructionism and racial naturalism are compatible-'biological race' and 'social race' just need to be distinguished.

The compatibility of social constructionism about race and racial naturalism does not present a metaphysical problem for social constructionists, but it does present some quite serious practical problems. Most social constructionists want their view to do something it cannot-entail a rejection of racial naturalism. The claim that there are social races does not rule out the possibility that there are also biological races. Social constructionists need to give race two definitions: one social, the other biological. To defend the claim that race isn't biologically real one must endorse some definition of biological race, and argue that the science does not support the existence of human biological races according to that definition. As studies have shown, the debate about the reality of biological race is far from over (Lieberman et al. 2004; Morning 2011; but see Wagner et al. 2016). By referring to 'race' simpliciter, social constructionists talk past race naturalists.

While some, like Hardimon, carefully distinguish between 'social race' and 'biological race', almost all social constructionists talk and write about 'race' simpliciter. This creates an ambiguity about the meaning of the term, an ambiguity which is especially problematic when it comes to public understanding of 'race'. There is widespread agreement that 'ordinary people' or non-specialists understand race as a biological category. The continued use of race as an analytic concept by social constructionists is likely to reinforce racial naturalism in the public imagination, even though it is the intention of most constructionists to distance 'race' from biology. As the sociologist Robert Miles explains, the use of the race concept "is particularly problematic when 'race relations' sociology reports its findings and conclusions to politicians, the media and the public in a historical context in which the nineteenth century idea of 'race' continues to be repro- 
duced" (1988: 10). Even if current conceptions of race are more flexible and to some extent less tainted by racism than those of the nineteenth century - which is in part the result of anti-racist work done by social constructionists - race is still generally understood as a biological concept. Unless social constructionists who are also anti-realists about biological race are able to distance 'race' from biology in the public imagination, they will give an academic stamp of approval to racial naturalism by their continued use of what has historically been a biological concept. In other words, the language used by social constructionists may inadvertently spread racial naturalism, even though most social constructionists do not believe that race is biologically real. ${ }^{3}$

\subsection{A Metaphysical Argument against Social Constructionism}

The arguments above are normative. They are not about whether race is real. Rather, they are about whether we ought to use the concept of race, and so only support eliminativism about race. The distinction between the normative and the metaphysical is not a sharp one, because what we include in our ontology is driven, in part, by normative considerations (Kincaid, Dupré, \& Wylie 2007). However, there is a distinction to be made between normative/eliminativist and metaphysical/anti-realist arguments. Eliminativists about race urge us to eliminate race from our speech, thoughts, and practices regardless of our metaphysical position on race. The anti-realist about race believes that race is not real according to certain standards, and may or may not endorse eliminativism. Anti-realists about biological race believe that race is not real according to biological standards. Anti-realists about social race believe that race is not real according to the standards of the humanities and social sciences. The standards are, of course, norms. Normativity therefore plays a role, but the conclusion is ontological, metaphysical.

Turning now to a metaphysical line of critique, I will argue that social constructionism suffers from a specificity problem. That is, on a social constructionist or social kind approach, race loses its historical and conceptual specificity, and thus its value as a conceptual resource. It would be a mistake, I believe, to conclude that social race is simply not what we thought it was. I argue that the right conclusion is to reject a social metaphysics of race, because 'social race' does not meet the standards of conceptual value we should expect in the humanities and social sciences.

The specificity problem is best approached from a historical perspective. There is a broad consensus that race is a modern concept and that 'social races'

3. For the race naturalist who is also a social constructionist, this will not be a concern. The ambiguity problem that such a theorist faces is to distinguish consistently between 'biological race' and 'social race'. This would be especially important if the groups were not thought to be identical. 
are products of modernity (Bernasconi 2001; Doron 2012; Goldberg 2002; Holt 2002; Mills 1998; Omi \& Winant 2015). However, this consensus is being called into question by scholars of the pre-modern (Hahn 2001; Heng 2011a, 2011b; Isaac 2004; McCoskey 2012; Nirenberg 2009; Ramey 2014; Thomas 2010; Whitaker 2015). What many of these pre-modernists are trying to demonstrate is that there were social groups with the properties social constructionists identify as 'racial' before modernity. This has implications for how 'social race' is defined. For instance, if modern forms of biologization do not play a necessary role in the formation of so-called social races, then such biologization cannot play a necessary role in the definition of 'social race'. However, if we strip 'social race' of these modern biological associations - as I argue we must - the category becomes vague and transhistorical, losing its value as a conceptual resource.

To begin, we will need to get clear on what it means to think of race as a social kind. Ronald Sundstrom offers an account of such kindhood:

A kind is real when its members are unified - held together by a number of shared properties. The properties that unify a kind vary with the domain .... A biological kind is unified by some significant biological relation .... Similarly, a human kind is real when unified by a significant social relation. (2002a: 95)

There are different, but largely overlapping accounts of the shared properties and social relations that make 'race' a social, or a human kind: Sundstrom (2002a) lists disparities in income, health, education, and housing; Sally Haslanger (2012: 132) emphasizes economic, political, and legal inequality; Paul Taylor (2000) and Esa Diaz-Leon (2015) focus on joint histories and shared experiences as the bonds that tie people together racially.

From a social constructionist perspective, race could thus be defined as a social kind, distinguished on the basis of real or imagined differences, which is used to differentially distribute power and privilege between groups who-as a result of their classification - have shared histories, experiences, and opportunities. Notice that I did not specify whether the differences used to distinguish between the social kinds are biological. What sort of kind 'race' is, and how 'races' are distinguished, potentially come apart. Pierce explains this point well when he writes that

a social-kind view need not take race to be a purely social phenomenon .... We might take races to be groups whose existence or significance depends on social factors but whose identifying characteristics are biological, e.g., phenotypical characteristics and/or ancestry. The biological traits would not distinguish these particular groups as races in some sci- 
entifically non-arbitrary way. Social practices do that job. But the social practices might single out these groups rather than others because of distinctive biological characteristics whose use to determine racial boundary lines is biologically arbitrary but socially explicable. (2014: 56-7)

This is the standard view among social constructionists. Race is social kind, not a biological kind, but it has biological inclusion criteria.

The standard view offers a way to locate race in historical time. Race is a social kind which is the product of a modern taxonomic project, a project which was used to justify the exploitation of those 'races' deemed inferior. This project was supposed to describe race as a biological kind, but it was in fact instrumental in creating race as a new social kind (Mallon 2015). By identifying racial formation with the modern taxonomic project, social constructionism piggy-backs on the consensus that biological race is a modern concept. However, if the social kind existed before the taxonomic project, the origins of 'race' are thrown into question.

One of the strongest cases for race before modernity has been made by Geraldine Heng, who argues that modern forms of biologization are not necessary for the creation of the kind of social groups that social constructionists call 'rac$\mathrm{es}^{\prime}$. She shows that such groups existed before the modern era (Heng 2011a, 2011b). Heng's focus is on Jewish-Christian relations in thirteenth-century England, which in many ways foreshadowed those in Weimar Germany. She argues that "the Jewish badge, expulsion order, legislative enforcements, surveillance and segregation, ritualised iterations of homicidal fables, and the legal execution of Jews are constitutive acts in the consolidation of a community of Christian English - otherwise internally fragmented and ranged along numerous divides - against a minority population that has, on these historical occasions and through these institutions and practices, entered into race" (Heng 2011b: 336; emphasis in original). Heng demonstrates, I believe decisively, that the thirteenth-century English Jewry meet the definition of a 'social race' before modernity.

Most social constructionists locate race only in the modern period. Those committed to this position could not respond to the above argument by simply adding biological criteria to their definitions of race. To legitimately add biological criteria as necessary to the concept, social constructions would need to demonstrate that the social kind that they call 'race' is only produced under particular conditions of biologization.

As it happens, almost all social constructionists already include biological criteria in their definitions of race. For example, some have stipulated that race has an ancestry component (Gracia 2005; Taylor 2004). This seems like common sense. However, Heng's example of Christian-Jewish relations in thirteenthcentury England shows this to be mistaken. Jewishness was not yet defined as 
'innate', as it would be in fifteenth-century Spain with the Purity of Blood Statutes (Nirenberg 2009). 'Social race' is not necessarily determined by ancestry, because until the fifteenth-century Jews - who, if we follow Heng, fit the description of a social race centuries earlier-could change their group membership by conversion (see Stacey 1992).

Social constructionists might accept that racial formation does not necessarily involve modern forms of biologization, but insist that race is modern for some other reason. For example, they could tie race to the creation of the modern nation state (Goldberg 2002), or to the development of white supremacist ideology (Mills 1997). I do not believe that such an approach is successful. In medieval Europe the church acted in many ways like a modern nation state. "The church's bid for an overarching authority and uniformity", writes Heng, "importantly furnished medieval societies with an array of models on how to consolidate unity, power, and collective identity across internal differences. A church with universalist ambitions in effect sought to function like a state, a state without borders" (Heng 2011b: 337). If this is right, then identifying race with the creation of the modern nation state appears artificial: groups fitting the description of 'social race' could be, and were, produced before the rise of the modern nation state.

A similar argument applies to the identification of race with white supremacist ideology. As Cord Whitaker notes, "the logic of race, with regard to whiteness and blackness, is already deeply ingrained in Latin Christian culture by the late Middle Ages" (Whitaker 2015: 5). There are numerous historical sources that show that as early as the thirteenth century, medieval societies were preoccupied with skin color, coding dark skin as 'evil' and white skin color as 'good' (Hahn 2001; Lampert 2004; Ramey 2014). White supremacist ideology became more virulent, more pervasive, more global, and more thoroughly institutionalized in modernity, but it is not modern in origin, and so does not cut history into pre-modern non-racial and modern racial periods.

My point is not that all is continuity - that being a member of a so-called 'social race' was the same in the thirteenth century as it was in the nineteenth century. That would be preposterous. My point is rather that the sort of social relations that social constructionists identify as kind-making, as race-making, were present before modernity. Once we start adding extra criteria-'races' must be biologized in a certain way; they are only produced in modern nation states, etc. - we have already given up on a social kind approach in favor of an approach which seeks to cut history into racial and pre-racial times. Even if a cutting approach worked-slicing history at 'the right time' - it would be artificial to identify 'race' with some uniquely modern phenomenon (e.g., the modern nation state) if the sort of social groups that social constructionists call 'races' were present before modernity. 
Of course social constructionists could simply accept that race is not modern, and that it is not necessarily produced under conditions of modern biologization. They could define race, as I suggest above, as a social kind distinguished on the basis of real or imagined differences, which is used to differentially distribute power and privilege between groups who have shared histories, experiences, and opportunities. This definition of race has, I think, a ring of plausibility. However, on close inspection it has extremely counterintuitive consequences. It would no longer be possible to distinguish between race and ethnicity, as race has lost its biological content. Race would be conflated with racism, as hierarchy is built into the definition of race. Worse still, men and women would count as 'races'. Men and women are differentiated on the basis of real or imagined difference, power is differentially distributed between them, and they each have shared histories, experiences, and opportunities. Even children and adults would count as different 'races' on the definition above. While we may be willing to accept that race is a vague concept, most would be unwilling to accept this variety of vagueness.

Heng is perhaps unique among social constructionists as she sees and accepts some of these kinds of counterintuitive consequences. She suggests, for instance, that in certain circumstances homosexuals can be conceptualized as a race (Heng 2011a: 319). I believe that this ought to count as a reductio ad absurdum against social constructionism about race. If race cannot be distinguished from other group concepts, such as ethnicity or sex, or from forms of prejudice, such as racism or homophobia, then the idea loses its conceptual value. We can just refer to structural discrimination or persecution instead. There has been structural discrimination between groups for all of recorded history. On a social definition 'race' does not only lose its conceptual specificity, it also loses its historical specificity-it becomes transhistorical. 4

The conclusion that we should draw from this is not merely eliminativist: that social race is real but we ought not to talk about it because of the specificity problem. Rather, we should draw an anti-realist conclusion: that social race is not real. The specificity problem shows that 'social race' has little conceptual value, and so attempting to construct a social metaphysics of race is a wrongheaded project.

The specificity problem does not arise on a biological definition of race. On the standard biological account, here expressed by Claude-Olivier Doron, two conditions needed to be met before race theory proper could emerge:

4. Others have argued in a similar way against attempts to locate race before modernity (Jordan 2001; Seth 2005; Mittman 2015). However, they do not seem to recognize that the 'continuity thesis' is merely the outcome of a social approach to 'race'. One cannot dismiss the idea of race before modernity without also rejecting social constructionism about race. 
1. The classificatory style of reasoning in natural history had to be subordinated to another way of reasoning, in which the primary question was that of origins, lineages and descent: we may call this the genealogical style of reasoning. It is this style of reasoning which one finds in nobility, in universal chronicles and in breeding practices. 2. Moreover, it implied that it was thought necessary to define a peculiar level of classification, which did not exactly correspond to the level of species nor of varieties, but constituted an intermediary category of uncertain status. This intermediary category was more stable than mere varieties - whose inconstancy did not permit any real classification - but less essential than specific differences. (2012: 87)

It was the joining of what Doron calls the classificatory and the genealogical style of reasoning in the eighteenth century (by, for example, Buffon and Kant) in attempts to divide the entire human species into major biological sub-groups that makes race a modern concept. ${ }^{5}$ To claim that the idea of race is modern is to claim that it only emerges as a relatively stable and coherent scientific concept during the period we call modernity (Bernasconi 2001; Doron 2012). This is not to downplay how the idea of race was mobilized politically and socially, nor to dismiss pre-modern conceptions of difference as irrelevant. Identifying race as a biological concept will only sharpen our theoretical tools. It will allow us to trace proto-racial theory - which was missing one or more of the key elements of 'race' - back to antiquity (Isaac 2004; McCoskey 2012). ${ }^{6}$ It will also allow us to trace pseudo-racial theory - which conflates 'race' with other concepts, such as 'nation' and 'population' - to the present day (Gannett 2013; Hudson 1996; Millstein 2015). Defining race biologically is good historical practice.

If we ought to define race biologically, but there are no biological races, then we must conclude that race doesn't exist. I now turn to anti-realism about race.

\section{Anti-Realist Reconstructionism}

Anti-realism about race is the view that 'race' fails to refer to anything in the world, that it is not real. As mentioned above, this is currently the least popular metaphysical position about race. In this section I argue that anti-realism about race is indeed the right metaphysical position, but that it needs to be supple-

5. See Jennifer Mensch's (2013) Kant's Organicism on the roles that Buffon and Kant played in developing natural history.

6. It will also be useful to look back to early ethnogenesis and to discourses surrounding 'barbarians' (Gillett 2004; 2006), which surely informed the racialization that was to follow. 
mented with realism about racialized groups, and a theory of racialization (to be provided in the following section).

Compared to social constructionism, anti-realism about race is relatively straightforward. There is no debate about what anti-realism really means. However, confusions do arise. Everyone is an anti-realist about race in some sense, simply because there are so many definitions of race floating around, some of which are incompatible. To call someone an anti-realist simpliciter (rather than an anti-realist about biological or social race) ought to imply that they are a comprehensive anti-realist: that they deny the validity of any racial ontology.

There are few philosophers who subscribe to a comprehensive anti-realism about race. Most of those who are cited as anti-realists about race do not, on close inspection, actually defend this view. For instance, Anthony Appiah, J. Angelo Corlett, Yehudi Webster, and Naomi Zack are commonly cited as defending antirealism about race. However, when one reads their work closely, it becomes clear that they do not reject the reality of race under all definitions of the word (Appiah 1996: 73; Corlett 2005: 571; Webster 1992: 2; Zack 2002: 106). They may be anti-realists under some or most definitions of 'race', but they are not comprehensive anti-realists. Rather, they are eliminativists about race. ${ }^{7}$

I would suggest, then, that 'anti-realism about race' should be used to refer to comprehensive anti-realism, and anti-realism should not be confused with eliminativism about race. With these clarifications made, what should we say about antirealism? Well, it seems that the case for anti-realism about race is clear and compelling. If race is best understood as a biological concept, and one which does not refer to a natural kind, then anti-realism is the right metaphysical position on the subject.

Nevertheless, 'race' may be a useful fiction. Social constructionists have made forceful arguments for the value of the race concept (Haslanger 2000; Mills 1998; Sundstrom 2002b; Taylor 2000). The constructionist argument in favor of retaining 'race' is well captured in the following passage by Sundstrom:

Wisps of human fancy or human creations they may be, but as social constructions they are absolutely penetrating and inescapable in our individual and communal lives, and they are just as absolutely fundamental to our investigations of the American social, political, and economic landscape. And frankly, to fight our fight, to end racism and "racial" disparities in income, health, education, and so on, we need to be able to coherently talk about "race". We need to be able to point to it, discover what it is and the role it plays in our lives. (2002b: 203)

7. Or they are at least eliminativists in most domains. Appiah has "no problem with people who want to use the word "race" in population genetics" (Appiah 1996: 73). 
Attempts to reduce 'race' to other categories have been largely unsuccessful, and this has been a major problem for anti-realism about race. Omi and Winant (2015) devote entire chapters to separating 'race' from 'ethnicity', 'class', and 'nation'. Albert Atkin, discussing 'race' in the Australian context, points out that

we might drop talk of race and simply talk about the tribal ethnic communities that the subjects we are interested in are from. However, once we start to talk about the rates of school completion among the Darug, Kuringgai or some other group, we begin to lose something from our explanation. Certainly the tribal group differences are worth acknowledging.... However, the decreased chances of employment experienced by a member of the Pindjarup are due not simply to their being a member of that group, but to the Pindjarup being one of the many groups of Indigenous Aboriginal peoples in Australia. (2012: 94)

Colonization and genocide happened not to individual Aboriginal ethnic groups but to the entire indigenous population. Indigenous Australians were not treated as self-defining ethnic groups, but as a whole-as a 'race'.

In the wrong hands, anti-realism about race could do a great deal of damage. As Naomi Zack writes, "belief in racial categories has become associated with efforts to eliminate racial injustice, and the news that such categories do not exist is often received as an attack on such efforts" (2001: 447). After all, if there are no races, it could be argued that there is no need to end current and make reparations for past injustices to racial groups, who, as anti-realists tell us, do not exist. So the anti-realist is morally obliged to replace 'race' with something else.

Blum (2010) is an anti-realist about race who fulfills what I believe to be the moral obligation of the anti-realist: he offers an alternative to racial ontology (see also Glasgow 2009). Blum argues that we should replace 'race' with the concepts of 'racialization' and the 'racialized group'. Miles $(1988 ; 1993)$ has been defending the same position for some time, but targeting sociologists rather than philosophers. Antonia Darder and Rodolfo Torres have also been defending this view outside of philosophy (Darder \& Torres 2003). I find the argument persuasive, and I am indebted to these scholars.

What is racialization, then, and what are racialized groups? ${ }^{8}$ I suggest the following definitions. Racialization refers to the process in which groups and individuals become mistakenly identified as belonging to biological 'races' with particular 'racial' characteristics. Racialization is not limited to groups and individuals, however. A social structure is racialized when there is stratification along racialized lines. Other phenomena are racialized when they are associated

8. For a history of the concept of racialization see Barot and Bird (2001). 
with 'race' (e.g., racialized dance, or hairstyles). A racialized group is a population mistakenly believed to be a biological race. ${ }^{9}$

It is important to note that while racialization happens from without-as when dominant groups racialize other groups - it also happens from within. As Steve Garner writes, there is a "broad agreement that racialization is something detrimental that is done to others as part of a power relationship. However, it should also be borne in mind that attaching meaning to one's own group as a 'race', and instilling this meaning with positive attributes ... is a common practice for subordinate groups seeking to defend and assert themselves collectively" (Garner 2009: 20). It is also common practice for dominant groups, such as whites. Whites are a predominantly self-racialized group.

\subsection{Objections and Clarifications}

Some have worried that an ontology of 'racialized groups' would entail that certain identities are not genuine. "Blum's substitutionism", writes Joshua Glasgow, "would require that those who care about being, say, black have to stop thinking of themselves as members of a race ... and instead conceive of themselves as members of erroneously racialized groups, so that their identities are, in some sense, fraudulent" (Glasgow 2009: 150). In response, Blum argues that,

To recognize that one's racial[ized] ancestors, and perhaps oneself, have been treated as if they possessed certain genetic deficiencies that they did not in fact possess does not involve having a falsehood-based identity. One's sense of peoplehood is indeed bound up with having been racialized, and racialization can be embraced by those who are racialized as a way to contest the inferiorization to which one or members of one's group are subject. The 'fraudulence' lies in the beliefs that have rationalized one's people's plight, not in the nature of the identity itself. (2010: 314)

Identifying with a racialized group (or indeed with more than one) does not entail buying into a lie. It does, however, raise the following puzzle. If the groups we call 'races' are actually racialized groups, could it be that 'race' and 'racialized group' can be used synonymously, with the consequence that race is real after all? Indeed, the term 'racialization' is typically understood by social constructionists to refer to the race-making process, the process by which social races are formed (e.g., Haslanger 2012: 237).

9. I add 'mistakenly' here because of my anti-realism about race. I see interactive constructionism about racialized groups as complementing anti-realism. 
One way of cashing this out theoretically would be to adopt a causalhistorical approach to reference. If the meaning of our terms "just ain't in the head", as Hilary Putnam argued, then perhaps we could be radically mistaken about what race is and still achieve reference when we talk about it (Putnam 1973). That is, when we talk about race-even when we are thinking of races as scientifically valid biological groups - we might really be talking about racialized groups. This would indeed be a consequence of Putnam's causal-historical theory of reference. If Putnam was right, maybe we can re-conceptualize 'races' as 'racialized groups' but keep on using the term 'race', despite my arguments against the category.

The strategy of trying to resolve metaphysical disputes by appealing to a putatively determinative theory of reference-the 'flight to reference' - has, I take it, been discredited (Bishop \& Stich 1998; Mallon, Machery, Nichols, \& Stich 2009; Stich 1996). There is no single way in which terms refer. For some terms a causal-historical approach works well (e.g., star, atom). For other terms a descriptive approach appears to be correct (e.g., phlogiston, natural place). Which theory of reference 'works' for any individual example is, according to Stich, determined by principles of rational ontological inference like those described by Larry Laudan's project of normative naturalism (Donovan, Laudan, \& Laudan 1988) and more or less arbitrary factors: implicit previous agreements about the properties necessary to a posited entity, and social and political factors both internal and external to the relevant field.

What this means for the metaphysics of race is that we cannot settle debates about racial ontology by appealing to a theory of reference (Mallon 2006). A theory of reference may well describe how the term 'race' refers or fails to refer if a consensus is someday reached. However, if the flight to reference is a mistake, then we should not appeal to a theory of reference in order to forge such a consensus. The sort of considerations I have been discussing are overriding, and do not hold the "correct account of race hostage to issues in the philosophy of language and metaphysics about which there is little agreement" (Mallon 2006: 548).

If we were to accept a causal-historical approach to reference as determinative, and identify racialized groups as races, this would blur a very useful distinction. As Blum (2010) argues, racialization should be understood as the process by which racialized groups - rather than 'races' - are formed. This approach gives us a way of conceptualizing the groups commonly called 'races' without reifying them. And it does not suffer from the central problem with unreconstructed anti-realism: that conventional 'racial' categories would have to be abandoned, along with the possibility of targeting these groups in public policy. The antirealist racialization theorist is able to recognize the reality of the groupings, but reconstruct our understanding of them. And at the same time, she can save the 
intuition that race is a biological concept. By defining race biologically, she can be very clear about what it is she is claiming does not exist.

The concept of the racialized group is more disruptive than the idea of social race, and this seems like an advantage. As J.L.A. Garcia explains, while a 'race' is something one has, "racialization is something that is done to a group, by some social agent, at a certain time, for a given period, in and through various processes, and relative to a particular social context" (Garcia 2003: 285). This suggests that the language of racialization is less likely to perpetuate false beliefs about the naturalness of racial classification than standard race-talk. Indeed, Blum (2004) has discussed the benefits of teaching the idea of racialization as a part of antiracist education.

It may appear that I am favoring a descriptive over a causal-historical approach to reference, and thus taking the flight to reference myself-the very move I am arguing against. That would be a misunderstanding of my position, and of the flight to reference. The critique of the flight to reference is only against the idea that there is a single true, and thus determinative, theory of reference. In some specific cases, something like a descriptive approach will be preferable, but that is not because a descriptive approach offers the correct account of reference relations. In other cases we should favor a causal-historical approach. For instance, a causal-historical approach may be preferable when changing the meaning of a term will not cause too much confusion. That is manifestly not the case with 'race'. Given the normative and metaphysical arguments against 'race', and those in favor of replacing 'race' with 'racialization' and 'racialized group', appealing to the causal-historical approach as a determinative theory of reference seems like a last-ditch attempt to save the category of race, and one which is unlikely to convince those who are not already committed to this position in the philosophy of language.

Before introducing interactive constructionism as a framework for understanding racialization, I will consider another possible objection: that my version of anti-realist reconstructionism also suffers from a specificity problem. I have already argued, following Robert Bernasconi and Doron, that 'race' emerges as a relatively stable and coherent scientific concept in the second half of the eighteenth century. However, the term 'race' and its cognates had already been used for hundreds of years. So even if we can, with some precision, locate race as a scientific concept historically, this leaves open the following question: when did racialization first occur?

We can answer this question by identifying racialization as taking place when the term 'race' is applied to human 'breeding groups,' or even when groups are understood in a certain way without being explicitly labelled as races. The earliest example of which I am aware of the term 'race' being used to describe 
human breeding groups was in fifteenth-century Spain. As David Nirenberg explains, "words like raza . . . were already embedded in identifiably biological ideas about animal breeding and reproduction in the first half of the fifteenth century ... the sudden and explicit application of this vocabulary to Jews coincides chronologically (the 1430s) with the appearance of an anti-converso ideology ... which sought to establish new religious categories and discriminations, and legitimate these by naturalizing their reproduction" (Nirenberg 2009: 252). If we think of racialization as taking place when a human group is called a 'race', then we can date racialization back to the fifteenth century.

While such an approach is appealing, it does not allow for what we might call 'covert racialization': racialization that takes place without the explicit naming of a group as a 'race'. For instance, when media outlets report attacks on Muslims as racist, this may have the effect of racializing Muslim people, even when they are not explicitly called a race. Perhaps, then, racialization can be understood to take place when groups are understood in a certain (biological) way. This would not necessarily involve fully-fledged race theory. For example, the race/species distinction as we know it-a distinction considered central to the development of a scientific concept of race-had not yet been drawn in fifteenth-century Spain. Nevertheless, the labelling of the Jews (and also the Moors) as a 'raza', and naturalizing their reproduction as 'in the blood', can be usefully understood as an instance of racialization (Nirenberg 2009).

To see this, consider a key difference for Jews in thirteenth-century England and fifteenth-century Spain. Jews in thirteenth-century England were not racialized: they were a religious group who were subject to structural persecution. Jewishness was, to some extent, biologized, in that it was associated with bodily characteristics, but Jews could convert, and many if not most of those characteristics were understood to disappear through conversion (Resnick 2000). In fifteenth-century Spain, on the other hand, Jewishness was deemed to be 'in the blood' and conversions were nullified. We can mark this difference as one of racialization.

Whether we take the explicit naming of a group as a race as determinative of racialization, or a certain biologized understanding of the group as also important, racialization appears to have first taken place in fifteenth-century Spain. The anti-realist racialization approach does not, therefore, suffer from the lack of conceptual and historical specificity that we find with a social kind approach to 'race'. Nevertheless, there will likely be trouble cases - particularly because racialization comes in degrees - and more work on this subject would be welcome. 


\section{Interactive Constructionism about Racialized Groups}

I have argued that we should replace 'race' with the concepts of racialization and the racialized group. I defined racialization, but this does not tell us how groups are racialized, or the ontological status of racialized groups. In this section I introduce interactive constructionism as a framework for understanding racialization, and I also respond to some possible criticisms.

\subsection{The Framework}

The reason we need a theory of racialization is straightforward. Social constructionists have racial formation theory to account for the way 'races' are created, inhabited, transformed, and destroyed. Anti-realists can't endorse racial formation theory because it assumes that race is real. Anti-realists need a theory of racialization, a theory which describes the formation of racialized groups, rather than 'races'.

I take, as a useful metaphor for racialization, the idea of constructive interactionism from DST. Recall that DST is a biological framework for understanding development, inheritance, and evolution. It proposes that every trait is the result of interactions between a wide range of developmental resources. Developmental systems theorists make the case that development occurs in a niche in which the resources necessary for ontogenesis are "contingently but more or less reliably reassembled for each life cycle" (Oyama et al. 2001: 1). It is the interaction between the many elements of the system that is responsible for development.

DST rejects metaphysical dichotomies such as gene/environment, nature/ nurture and biology/culture in favor of a concern with developmental systems as a whole. Developmental systems theorists argue that these dichotomies have outlived their usefulness (Griffiths \& Hochman 2015). DST is sometimes misinterpreted as the idea that all developmental factors (genetic, epigenetic, 'environmental', etc.) are the same or just as important as each other. The idea is rather that no interactant has a metaphysical privilege. Genes, for instance, do not exclusively control development, and they are not the only developmental resource that is inherited (Griffiths \& Hochman 2015).

Drawing on DST, interactive constructionism is the view that racialization is a process involving a wide range of interactants, which are jointly involved in the production of racialized groups. On the interactive constructionist approach, racialized groups emerge out of the ongoing interaction between a number of factors: administrative, biological, cultural, economic, geographic, gendered, ${ }^{10}$

10. Intersectionality theorists have shown that how you (as an individual) are racialized depends on your gender (Carastathis 2016). However, it may be less apparent how gender is relevant to racialization on the group level. As a starting point, consider how "social theory concerning 
historical, lingual, phenomenological, political, psychological, religious, social, and so on. Interactive constructionism rejects the metaphysical privileging of any of these interactants as the key to what racialized groups 'really are'. The importance of any given interactant will depend on the context, and can change over time. ${ }^{11}$ None of these interactants are 'racial'. Yet together, in interaction, they can produce racialization. And just as groups can undergo a process of racialization, they can be deracialized over time. Racialization is not an all or nothing affair. As Blum (2002) points out, groups can be partly racialized.

Interactive constructionism offers a way of conceptualizing human biological diversity without reinstating race as a valid biological category. How a person is racialized depends, in part, on the interpretation (by a particular group and at a particular time and place) of biological traits such as skin color, hair type, eye shape, and so on. Contra racial naturalism, biological traits alone cannot determine racialization because human biological diversity is comprised of characteristics that are predominantly smooth in their distribution across geographic space and have different distribution patterns depending on which trait is selected (Barsh 2003; Zack 2002). In technical terms, we would say that human biological diversity is composed primarily of discordant clines. So interactive constructionism includes biology as a factor in racialization, but human biological diversity is not understood as racial.

On a systems approach to racialization we should expect there to be interactions between (non-racial) biological difference and other factors in the racialization process. We should also expect biological difference to be more or less important at different points in history, and in different places. This is exactly what we find. Kant's racial taxonomy was color-coded (Kant 1777/2000). However, once we move from the eighteenth to the nineteenth century, 'race' was conflated with 'nation'. As Nicholas Hudson writes, "Pseudoscientific studies of 'race' ... focused on racial differences between ever smaller groups. British, Irish, Saxons, Aryans, Jews, even 'Americans' (that is, citizens of the United States) were all, at one time or another, vaunted or condemned as 'races'” (Hudson 1996: 258). It would be very difficult to classify people into these groups by their visible biological features. For a period, then, visible biological difference played a less important role in racialization. However, as more light-skinned groups were elicited into the 'white race' in the early to mid$20^{\text {th }}$ century, visible biological difference became-once again-central to race thinking (Carter 2007). The importance of visible biological differences in the

gender and race has tended to proceed as if 'all the women are white, all the blacks are men"' (Bright, Malinsky, \& Thompson 2016). Gender certainly plays a role on the group level as well.

11. Interactive constructionism is fundamentally historicist. Rather than asking, for instance, "to which race(s) did 'mixed' German diaspora in Oceania belong", the interactive constructionist asks, "how did racialization operate in this particular context?" (see Winter 2015). 
racialization process waxes and wanes in interaction with other factors: social, political, economic, and so on. ${ }^{12}$

This sort of interaction can also be observed on the individual level. Anyone who has 'passed' knows something about how this works. How you dress, how you talk, how you act, and what you know, all play a role in whether you are able to pass as being from a racialized group other than the one you are usually associated with. For many of us 'passing' is almost impossible because we have biological traits that are strongly associated with a particular racialized group. This is not because race is biologically real, but rather because people occupy different locations on the various clines of human biological difference (some of which are racialized, such as skin color). Whether you can 'pass' depends not simply on your visible biological make-up, but on a complex interaction between this factor and others, such as how you dress, talk and act. This is one more reason why we should want a systems approach to racialization.

Interactive constructionism makes breadth central. Most feel quite comfortable including historical analysis, political analysis, and cultural analysis under the rubric of 'the social', but less so biological analysis, or even, for that matter, psychological analysis. ${ }^{13}$ Individual mental processes uphold social and political forces, so it is wrong to think that we have a full explanation once we deal with the social, historical, political and biological factors behind racialization. As Michael Rustin puts it, "a crucial means by which structures are upheld is through irrational mental processes, and ... this dimension needs to be recognised and confronted as such" (Rustin 1991: 71). We therefore need to take seriously the role that psychology plays in racialization. "Without some sense of the emotional intensity of race's appeal", argued Patrick Wolfe, "we cannot begin to account for it, let alone do anything about it" (2002: 53). And without the conceptual resources of psychology we cannot hope to account for this appeal.

At the risk of sounding imperialistic, most work done on the topic of 'race' could be absorbed into an interactive constructionist framework. As Ron Mallon has argued, there is now widespread agreement about the facts relevant to the debate about the nature and reality of race. This makes the idea of an overarching framework plausible:

Skeptics say race does not exist, employing the term 'race' to mean something that everyone agrees does not exist. Constructionists insist that race does exist, again employing the term 'race' to pick out phenomena that everyone agrees exist. And naturalists insist that races existed and might

12. For another example of how visible biological difference can interact with other factors, see Sarah Walsh (2015) on how Chileans claimed whiteness in the early $20^{\text {th }}$ century.

13. To explore all of the interactants I have listed would be beyond the scope of this paper. I take it as uncontroversial that they, and indeed others, play a role in racialization. 
still exist, using the term 'race' to pick out biological populations that are substantially different from the kinds whose existence eliminativists deny. (Mallon 2006: 547)

If there is a broad consensus about the facts, then the factual claims made by anti-realists, social constructionists, and race naturalists should be able to fit together in one overarching framework. By including both the biological and the social in the metaphysics of racialization, interactive constructionism provides such a framework.

\subsection{Objections and Clarifications}

I will now consider three possible objections to interactive constructionism about racialized groups, with the aim of clarifying the view. First, one might argue that race naturalists and social constructionists are already interactionists, and that interactive constructionism does not bring anything new. For instance, some race naturalists accept that social forces play a role in shaping biological 'races' (Kitcher 1999; Outlaw 1996; Spencer 2015), and perhaps all social constructionists believe that biological diversity is a part of the raw materials out of which 'social races' are formed.

However, these are weak forms of interactionism, according to which many factors influence race, but race is essentially biological or social. Race naturalists define race as a biological kind, giving a metaphysical privilege to the biological. They may claim that social factors influence our biology, but if race is a biological kind, then its reality (or lack thereof) is ultimately to be determined on biological grounds. What race is, and whether it is real, is still an entirely biological issue. In this way, race naturalists are committed to privileging biological factors, and their interactionism can only be of a weak variety.

Similarly, social constructionism confers a metaphysical privilege to the social, and so can only involve a weak form of interactionism. If race is a social kind, its reality is ultimately social. Biology can only play a peripheral role for the social constructionist, just as social forces can only play a peripheral role for the race naturalist. Just as the race naturalist must accept that biological races could be produced without social forces playing a role, social constructionists must accept that there could be social races that are not created under modern conditions of biologization, a consequence which results in the specificity problem described above.

One social constructionist does seem to endorse a strong form of interactionism, and this presents a puzzle. In A Realist Metaphysics of Race, Pierce argues that "the biological component of the social construction matters. Social constructions based on existing features of the world, however arbitrarily put together, 
do not thereby generate groups of things classified according to the construction. They just give them social significance" (2014: 89). Pierce calls his view a social kind approach, but I am not sure that this best describes his position. Just as chemical kinds are composed of chemical properties and relations, social kinds are composed of social properties and relations. Pierce does not argue that race is a social kind, but rather that social practices pick out pre-existing but biologically arbitrary groups and make them socially significant. His might be called a social significance view, rather than a social kind view. Because Pierce does not metaphysically privilege the social, he can avoid some of my criticisms of social constructionism. However, if the distinction between racial naturalism, social constructionism, and anti-realism is a metaphysical one, his view no longer fits neatly into any of these categories. Pierce's view may actually be closest to interactive constructionism about racialized groups, and our main disagreement may turn on issues in philosophy of language surrounding reference.

Let us consider a second line of objection. Social constructionists may insist that we privilege social factors by considering them as constitutive of group membership. If we do not offer a metaphysical privilege to either the biological or the social, as interactive constructionism suggests, how can we determine group membership in cases where social and biological factors point in different directions? Consider, for instance, African Americans with high proportions of recent European ancestry who grow up and live in typical social positions as African Americans, and who are identified by themselves and others as such. Race naturalists may identify these individuals as white. Social constructionists may argue that this is a mistake, that we should privilege social factors in determining their 'race'. What does the interactive constructionist say in such a case? Does the interactive constructionist approach entail that we need to weigh the biological and social factors equally? This seems to leave group membership underspecified.

This criticism misses the mark. Just as DST does not claim that all developmental factors are just as important as each other, but rather that no single factor has a metaphysical privilege, the interactive constructionist rejects any a priori privilege of the biological or the social. Interactive constructionism does not entail that biological, social, and other factors make equal causal contributions to the formation of racialized groups, whatever that may mean. On an interactive constructionist approach, there are no universal criteria for group membership. To return to the example above, if a person has a high proportion of recent European ancestry, but also has recent African ancestors and is racialized as black, it does not make sense on an interactive constructionist account to ask, "but what is she, really?" Interactive constructionism does not prescribe how we ought to classify people. Rather, it offers descriptive framework for understanding how racialization works. 
Let us consider a third and final objection. While interactive constructionism rejects racial naturalism, it still includes a role for biology in racialization. Some may worry that, by including biology in the picture, we risk opening the door to hereditarian explanations of differences between racialized groups. This worry would apply much more directly to the race naturalist, who believes that there are biological races. The almost universal response of race naturalists (or at least those in philosophy departments) has been to sanitize 'race', removing from the concept the racist associations of the past, and to cite works demonstrating the poor scientific standing of hereditarianism (e.g., Gould 1996; Kaplan 2015; Nisbett 2005; Nisbett et al. 2012; Suzuki \& Aronson 2005). The interactive constructionist rejects racial ontology, and so has an easier time with the objection. There cannot be inborn psychological or moral differences between 'the races' if there are no races. Any hereditarian reading of interactive constructionism would be a misinterpretation of the view. Racialized groups do not form valid biological categories, about which one could logically ask these sorts of questions.

While it may seem that the social constructionist who is also an anti-realist about biological race avoids these sorts of misinterpretations, this is not the case. Social constructionism is often misinterpreted by hereditarians as the view that there are absolutely no statistical differences in any biological traits (even skin color) between conventional 'racial' groups (e.g., Sesardic 2013). Nobody in the debate actually seems to hold this view (Hochman 2016b). Nevertheless, the social constructionist straw-man is derided as absurd, and it is against this background of apparent absurdity that not only racial naturalism, but also hereditarianism, is advanced.

It is probably impossible to insulate any view on this topic from misinterpretation. Interactive constructionism is unlikely to be misinterpreted in the way social constructionism is misinterpreted. However, by including biology and psychology as interactants in the racialization process, it may risk being misunderstood along hereditarian lines. The point, however, is not that there are biological races with innate psychological differences, but rather that there are racialized groups with vague and arbitrary biological inclusion criteria, and that there are psychological explanations for the practice of racialization itself (Clarke 2003; Dalal 2002; Hochman 2013b; Machery \& Faucher 2005; Smith 2011). Interactive constructionism offers no support or intellectual basis for hereditarianism.

\section{Conclusion}

It is now uncontroversial that we are not a very genetically diverse species, that our biological diversity is composed primarily of discordant clines, and that there is nothing scientifically privileged about conventional 'racial' classifica- 
tion. Race naturalists have thus been forced to trivialize 'race' to accommodate the facts about human biological diversity, and they have conflated 'race' with other concepts, such as 'population', in attempts to retain the category.

Social constructionism about race is the preferred approach among humanities scholars. However, I have argued that it has some quite serious problems. Most social constructionists believe that their view entails a rejection of racial naturalism. However, a social ontology of race is compatible with a biological one, so social constructionism cannot play the role most of its proponents want it to play. Social constructionism actually introduces an ambiguity about the meaning of 'race'. This ambiguity, I have argued, is particularly problematic when it comes to public understanding, given how deeply entrenched biological conceptualizations of race are among non-specialists.

Defining race as a social kind also leads to a metaphysical problem. The specificity of 'race' depends on the biological content of the concept. By defining race as a social kind, constructionists can only establish a necessary link between race and biology if they can show that particular forms of biologization are necessary for the creation of the sort of groups they want to call 'races'. I have argued that they cannot show this, and that 'race' therefore loses its conceptual and historical specificity. Attempts to construct a social metaphysics of race are unsuccessful.

Race is best understood as a biological concept which fails to refer. However, anti-realism presents a pressing problem. It leaves the phenomena race naturalists and social constructionists are interested in unexplained. A race-like category seems necessary, especially for affirmative action and reparations programs. So, if we want to be anti-realists we need to find a new way to talk about the groups that are conventionally labelled 'races'. I argued that we ought to replace 'race' with the companion concepts of 'racialization' and 'racialized group'.

I then introduced interactive constructionism as a theory of racialization for anti-realists about race. Drawing on DST, I proposed that racialized groups are the joint products of a range of interactants, the importance of which will depend on the context. Racialized groups are not simply social constructs, they are administrative, biological, cultural, economic, geographic, gendered, historical, lingual, phenomenological, political, psychological, religious, and social constructs. ${ }^{14}$ Interactive constructionism broadens the construction process, and signals a shift in ontology from 'racial' groups to racialized groups.

Getting the metaphysics right is a philosophical challenge. At the risk of stating the obvious, solving this philosophical challenge will not end the individual and structural racism that bedevils society. Conceptual clarification may, however, have some role to play. As Darder and Torres maintain, "A persistence in attributing the idea of 'race' with analytical status can only lead us further down

14. This list is not presumed to be exhaustive. 
a theoretical and political dead end" (2003: 103). Interactive constructionism is an attempt to redirect theoretical and political efforts away from a dead end. Attempts to revive race as a biological category have trivialized the concept and conflated it with other categories. Social constructionism leads us "simply to bury the biological conception below the surface, not to transcend it" (Appiah 1985: 34). Interactive constructionism is an attempt to transcend 'race'.

\section{Acknowledgments}

I would like to thank Paul Griffiths, Jonathan Kaplan, Philip Kitcher, Edouard Machery and Frances Olive for their valuable feedback on this work in an earlier stage of development. Thanks also to two anonymous reviewers for their very helpful and constructive comments. This work was funded by a Macquarie University Research Fellowship.

\section{References}

Appiah, Anthony (1985). The Uncompleted Argument: Du Bois and the Illusion of Race. Critical Inquiry, 12(1), 21-37. https://doi.org/10.1086/448319

Appiah, Anthony (1996). Race, Culture, Identity: Misunderstood Connections. In Anthony Appiah and Amy Gutmann (Eds.), Color Conscious: The Political Morality of Race (30-105). Princeton University Press.

Atkin, Albert (2012). The Philosophy of Race. Routledge.

Barot, Rohit and John Bird (2001). Racialization: The Genealogy and Critique of a Concept. Ethnic and Racial Studies, 24(4), 601-618. https://doi.org/10.1080/01419870120049806

Barsh, Gregory S. (2003). What Controls Variation in Human Skin Color? PLoS Biology, I(1), 19-22. https://doi.org/10.1371/journal.pbio.0000027

Bernasconi, Robert (2001). Who Invented the Concept of Race? Kant's Role in the Enlightenment Construction of Race. In Robert Bernasconi (Ed.), Race (11-36). Blackwell.

Bishop, Michael A. and Stephen P. Stich (1998). The Flight to Reference, or How Not to Make Progress in the Philosophy of Science. Philosophy of Science, 65(1), 33-49. https://doi.org/10.1086/392625

Blum, Lawrence (2002). "I'm Not a Racist, but ..." The Moral Quandary of Race. Cornell University Press.

Blum, Lawrence (2004). Systemic and Individual Racism, Racialization and Antiracist Education: A Reply to Garcia, Silliman and Levinson. Theory and Research in Education, 2(1), 49-74. https://doi.org/10.1177/1477878504040577

Blum, Lawrence (2010). Racialized Groups: The Sociohistorical Consensus. The Monist, 93(2), 298-320. https://doi.org/10.5840/monist201093217

Bobo, Lawrence D. (2008). Foreword. In Barbara A. Koenig, Sandra Soo-Jin Lee, and Sarah S. Richardson (Eds.), Revisiting Race in a Genomic Age (ix-xii). Rutgers University Press. 
Bright, Liam K., Daniel Malinsky, and Morgan Thompson (2016). Causally Interpreting Intersectionality Theory. Philosophy of Science, 83(1), 60-81. https://doi. org/10.1086/684173

Carastathis, Anna (2016). Intersectionality: Origins, Contestations, Horizons. University of Nebraska Press.

Carter, Julian B. (2007). The Heart of Whiteness: Normal Sexuality and Race in America, 18801940. Duke University Press. https://doi.org/10.1215/9780822389583

Clarke, Simon (2003). Social Theory, Psychoanalysis, and Racism. Palgrave Macmillan. https://doi.org/10.1007/978-1-137-09957-0

Corlett, J. Angelo (2005). Race, Racism, and Reparations. Journal of Social Philosophy, 36(4), 568-585. https://doi.org/10.1111/j.1467-9833.2005.00295.x

Dalal, Farhad (2002). Race, Colour and the Processes of Racialization: New Perspectives from Group Analysis, Psychoanalysis, and Sociology. Brunner-Routledge.

Darder, Antonia, and Rodolfo D. Torres (2003). Shattering the "Race" Lens: Toward a Critical Theory of Racism. In Antonia Darder, Marta Baltodano, and Rodolfo D. Torres (Eds.), The Critical Pedagogy Reader (245-261). Routledge Falmer.

Diaz-Leon, Esa (2015). In Defence of Historical Constructivism about Races. Ergo, 2(21), 547-562. https://doi.org/10.3998/ergo.12405314.0002.021

Donovan, Arthur, Larry Laudan, and Rachel Laudan (1988). Scrutinizing Science: Empirical Studies of Scientific Change. Kluwer Academic Publishers. https://doi.org/10.1007/97894-009-2855-8

Doron, Claude-Olivier (2012). Race and Genealogy: Buffon and the Formation of the Concept of "Race". Humana.Mente Journal of Philosophical Studies, 22, 75-109.

Fujimura, Joan H., Deborah A. Bolnick, Ramya Rajagopalan, Jay S. Kaufman, Richard C. Lewontin, Troy Duster, ... Jonathan Marks (2014). Clines Without Classes How to Make Sense of Human Variation. Sociological Theory, 32(3), 208-227. https://doi. org/10.1177/0735275114551611

Gannett, Lisa (2010). Questions Asked and Unasked: How by Worrying Less about the 'Really Real' Philosophers of Science Might Better Contribute to Debates about Genetics and Race. Synthese, 177, 363-385. https://doi.org/10.1007/s11229-010-9788-1

Gannett, Lisa (2013). Theodosius Dobzhansky and the Genetic Race Concept. Studies in History and Philosophy of Biological and Biomedical Sciences, 44, 250-261. https://doi. org/10.1016/j.shpsc.2013.04.009

Garcia, Jorge L. A. (2003). Three Scalarities: Racialization, Racism, and Race. Theory and Research in Education, 1(3), 283-302. https://doi.org/10.1177/1477878503001003002

Garner, Steve (2009). Racisms: An Introduction. SAGE Publications Limited.

Gillett, Andrew (2004). Introduction: The Barbarian: The Alien in Antiquity. Ancient History: Resources for Teachers, 34(1), 1-9. https://doi.org/10.1353/fro.2006.0005

Gillett, Andrew (2006). Ethnogenesis: A Contested Model of Early Medieval Europe. History Compass, 4(2), 241-26o. https://doi.org/10.1111/j.1478-0542.2006.00311.x

Glasgow, Joshua (2006). A Third Way in the Race Debate. Journal of Political Philosophy, 14(2), 163-185. https://doi.org/10.1111/j.1467-9760.2006.00238.x

Glasgow, Joshua (2009). A Theory of Race. Routledge.

Glasgow, Joshua and Jonathan M. Woodward (2015). Basic Racial Realism. Journal of the American Philosophical Association, 1(3), 449-466. https://doi.org/10.1017/apa.2015.7

Goldberg, David T. (2002). The Racial State. Blackwell Publishing.

Gould, Stephen J. (1996). The Mismeasure of Man. WW Norton \& Company. 
Gracia, Jorge J. E. (2005). Surviving Race, Ethnicity, and Nationality: A Challenge for the 21st Century. Rowman \& Littlefield Publishers.

Griffiths, Paul and Adam Hochman (2015). Developmental Systems Theory. In eLS. John Wiley \& Sons, Ltd. https://doi.org/10.1002/9780470015902.a0003452.pub2

Hahn, Thomas (2001). The Difference the Middle Ages Makes: Color and Race before the Modern World. Journal of Medieval and Early Modern Studies, 31(1), 1-37. https://doi. org/10.1215/10829636-31-1-1

Hardimon, Michael O. (2013). Race Concepts in Medicine. Journal of Medicine and Philosophy, 38, 6-31. https://doi.org/10.1093/jmp/jhs059

Haslanger, Sally (2000). Gender and Race: (What) Are They? (What) Do We Want Them to Be? Noûs, 34(1), 31-55. https://doi.org/10.1111/0029-4624.00201

Haslanger, Sally (2012). Resisting Reality: Social Construction and Social Critique. Oxford University Press. https://doi.org/10.1093/acprof:oso/9780199892631.001.0001

Heng, Geraldine (2011a). The Invention of Race in the European Middle Ages I: Race Studies, Modernity, and the Middle Ages. Literature Compass, 8(5), 315-331. https:// doi.org/10.1111/j.1741-4113.2011.00790.x

Heng, Geraldine (2011b). The Invention of Race in the European Middle Ages II: Locations of Medieval Race. Literature Compass, 8(5), 332-350. https://doi.org/10.1111/ j.1741-4113.2011.00795.x

Hochman, Adam (2013a). Against the New Racial Naturalism. The Journal of Philosophy, 110(6), 331-351. https://doi.org/10.5840/jphil2013110625

Hochman, Adam (2013b). Do We Need a Device to Acquire Ethnic Concepts? Philosophy of Science, 8o(5), 994-1005. https://doi.org/10.1086/673896

Hochman, Adam (2013c). Racial Discrimination: How Not to Do It. Studies in History and Philosophy of Biological and Biomedical Sciences, 44(3), 278-286. https://doi.org/10.1016/j. shpsc.2013.03.003

Hochman, Adam (2014). Unnaturalised Racial Naturalism. Studies in History and Philosophy of Biological and Biomedical Sciences, 46, 79-87. https://doi.org/10.1016/j.shpsc.2014.05.002

Hochman, Adam (2016a). In Defense of the Metaphysics of Race. Philosophical Studies. Advance online publication. doi:10.1007/s11098-016-0806-o

Hochman, Adam (2016b). Race: Deflate or Pop? Studies in History and Philosophy of Biological and Biomedical Sciences, 57, 6o-68. https://doi.org/10.1016/j.shpsc.2016.03.003

Holt, Thomas C. (2002). The Problem of Race in the Twenty-First Century. Harvard University Press.

Hudson, Nicholas (1996). From "Nation" to "Race": The Origin of Racial Classification in Eighteenth-Century Thought. Eighteenth-Century Studies, 29(3), 247-264. https://doi. org/10.1353/ecs.1996.0027

Hunley, Keith L., Graciela S. Cabana, and Jeffrey C. Long (2015). The Apportionment of Human Diversity Revisited. American Journal of Physical Anthropology, 160(4), 561569. https://doi.org/10.1002/ajpa.22899

Isaac, Benjamin (2004). The Invention of Racism in Classical Antiquity. Princeton University Press.

Jordan, William C. (2001). Why "Race"? Journal of Medieval and Early Modern Studies, 31(1), 165-173. https://doi.org/10.1215/10829636-31-1-165

Kant, Immanuel (1777/2000). Of the Different Human Races. In Robert Bernasconi and Tommy L. Lott (Eds.), The Idea of Race (8-22). Hackett Publishing. 
Kaplan, Jonathan M. (2015). Race, IQ, and the Search for Statistical Signals Associated with so-Called " $X$ "-Factors: Environments, Racism, and the "Hereditarian Hypothesis". Biology \& Philosophy, 3o(1), 1-17. https://doi.org/10.1007/s10539-014-9428-0

Keita, Shomarka Omar Yahya, Rick A. Kittles, Charmaine D. M. Royal, George E. Bonney, Paulette Furbert-Harris, Georgia M. Dunston, and Charles N. Rotimi (2004). Conceptualizing Human Variation. Nature Genetics, 36(11), S17-S20. https://doi. org/10.1038/ng1455

Kincaid, Harold, John Dupré, and Alison Wylie (2007). Value-Free Science: Ideals or Illusions? Oxford University Press. https://doi.org/10.1093/acprof:oso/9780195308969.001.0001

Kitcher, Philip (1999). Race, Ethnicity, Biology, Culture. In Leonard Harris (Ed.), Racism (87-120). Humanity Books.

Kitcher, Philip (2007). Does 'Race' Have a Future? Philosophy E Public Affairs, 35(4), 293317. https://doi.org/10.1111/j.1088-4963.2007.00115.x

Lampert, Lisa (2004). Race, Periodicity, and the (Neo-) Middle Ages. Modern Language Quarterly, 65(3), 391-421. https://doi.org/10.1215/00267929-65-3-391

Lemeire, Olivier (2016). Beyond the Realism Debate: The Metaphysics of 'Racial' Distinctions. Studies in History and Philosophy of Biological and Biomedical Sciences, 59, 47-56. https://doi.org/10.1016/j.shpsc.2016.08.001

Leroi, Armand (2005). A Family Tree in Every Gene. Journal of Genetics, 84(1), 3-6. https:// doi.org/10.1007/BF02715883

Lewontin, R. C. (1972). The Apportionment of Human Diversity. In Theodosius Dobzhansky, Max K. Hecht, and William C. Steere (Eds.), Evolutionary Biology (Vol. 6, 381398). Meredith Publishing Company. https://doi.org/10.1007/978-1-4684-9063-3_14

Lieberman, Leonard, Katarzyna A. Kaszycka, Antonio J. Martinez Fuentes, Leonid Yablonsky, Rodney C. Kirk, Goran Štrkalj, . . . Li Sun (2004). The Race Concept in Six Regions: Variation without Consensus. Collegium Antropologicum, 28(2), 907-921.

Ludwig, David (2015). Against the New Metaphysics of Race. Philosophy of Science, 82(2), 244-265. https://doi.org/10.1086/680487

Machery, Edouard and Luc Faucher (2005). Social Construction and the Concept of Race. Philosophy of Science, 72, 1208-1219. https://doi.org/10.1086/508966

Mallon, Ron (2004). Passing, Traveling and Reality: Social Constructionism and the Metaphysics of Race. Nô̂s, 38(4), 644-673. https://doi.org/10.1111/j.0029-4624.2004.00487.x

Mallon, Ron (2006). 'Race': Normative, Not Metaphysical or Semantic. Ethics, 116(3), 525-551. https://doi.org/10.1086/500495

Mallon, Ron (2015). Social Construction and Achieving Reference. Nô̂s, 1-19. doi:10.1111/ nous.12107

Mallon, Ron, Edouard Machery, Shaun Nichols, and Stephen Stich (2009). Against Arguments from Reference. Philosophy and Phenomenological Research, 79(2), 332-356. https://doi.org/10.1111/j.1933-1592.2009.00281.x

McCoskey, Denise Eileen (2012). Race: Antiquity and Its Legacy. IB Tauris.

McPherson, Lionel K. (2015). Deflating 'Race'. Journal of the American Philosophical Association, I(4), 674-693. https://doi.org/10.1017/apa.2015.19

Mensch, Jennifer (2013). Kant's Organicism: Epigenesis and the Development of Critical Philosophy. University of Chicago Press. https://doi.org/10.7208/chicago/9780226022031.001.0001

Miles, Robert (1988). Beyond the "Race" Concept: The Reproduction of Racism in England. Sydney Studies in Society and Culture, 4, 7-31. 
Miles, Robert (1993). Racism after 'Race Relations'. Routledge.

Mills, Charles W. (1997). The Racial Contract. Cornell University Press.

Mills, Charles W. (1998). Blackness Visible: Essays on Philosophy and Race. Cornell University Press.

Millstein, Roberta L. (2015). Thinking about Populations and Races in Time. Studies in History and Philosophy of Biological and Biomedical Sciences, 52, 5-11. https://doi. org/10.1016/j.shpsc.2015.02.001

Mittman, Asa S. (2015). Are the 'Monstrous Races' Races? Postmedieval: A Journal of Medieval Cultural Studies, 6(1), 36-51.

Morning, Ann (2011). The Nature of Race: How Scientists Think and Teach about Human Difference. University of California Press.

Nirenberg, David (2009). Was There Race before Modernity? The Example of 'Jewish' Blood in Late Medieval Spain. In Miriam Eliav-Feldon, Benjamin Isaac, and Joseph Ziegler (Eds.), The Origins of Racism in the West (232-264). Cambridge University Press.

Nisbett, Richard E. (2005). Heredity, Environment, and Race Differences in IQ: A Commentary on Rushton and Jensen (2005). Psychology, Public Policy, and Law, 11(2), 302210. https://doi.org/10.1037/1076-8971.11.2.302

Nisbett, Richard E., Joshua Aronson, Clancy Blair, William Dickens, James Flynn, Diane F. Halpern, and Eric Turkheimer (2012). Group Differences in IQ Are Best Understood as Environmental in Origin. American Psychologist, 67(6), 503-504. https://doi. org/10.1037/a0029772

Omi, Michael and Howard Winant (2015). Racial Formation in the United States (3rd ed.). Routledge.

Outlaw, Lucius T. (1996). On Race and Philosophy. Routledge.

Oyama, Susan, Paul E. Griffiths, and Russell D. Gray (2001). Cycles of Contingency: Developmental Systems and Evolution. MIT Press.

Pierce, Jeremy (2014). A Realist Metaphysics of Race: A Context-Sensitive, Short-Term Retentionist, Long-Term Revisionist Approach. Lexington Books.

Putnam, Hilary (1973). Meaning and Reference. The Journal of Philosophy, 70(19), 699-711. https://doi.org/10.2307/2025079

Ramey, Lynn T. (2014). Black Legacies: Race and the European Middle Ages. University Press of Florida. https://doi.org/10.5744/florida/9780813060071.001.0001

Relethford, John H. (2009). Race and Global Patterns of Phenotypic Variation. American Journal of Physical Anthropology, 139(1), 16-22. https://doi.org/10.1002/ajpa.20900

Resnick, Irven M. (2000). Medieval Roots of the Myth of Jewish Male Menses. Harvard Theological Review, 93(3), 241-264.

Rustin, Michael (1991). The Good Society and the Inner World. Verso.

Serre, David and Svante Pääbo (2004). Evidence for Gradients of Human Genetic Diversity within and among Continents. Genome Research, 14, 1679-1685. https://doi. org/10.1101/gr.2529604

Sesardic, Neven (2013). Confusions about Race: A New Installment. Studies in History and Philosophy of Biological and Biomedical Sciences, 44(3), 287-293. https://doi.org/10.1016/j. shpsc.2013.03.005

Seth, Vanita (2005). The Tyranny of Race. Thesis Eleven, 81(1), 91-102. https://doi. org/10.1177/0725513605051616

Smith, David L. (2011). Less than Human: Why We Demean, Enslave, and Exterminate Others. St. Martin's Press. 
Spencer, Quayshawn (2014a). A Radical Solution to the Race Problem. Philosophy of Science, 81(5), 1025-1038. https://doi.org/10.1086/677694

Spencer, Quayshawn (2014b). The Unnatural Racial Naturalism. Studies in History and Philosophy of Biological and Biomedical Sciences, 46, 38-43. https://doi.org/10.1016/j. shpsc.2014.02.005

Spencer, Quayshawn (2015). Philosophy of Race Meets Population Genetics. Studies in History and Philosophy of Biological and Biomedical Sciences, 52, 46-55. https://doi. org/10.1016/j.shpsc.2015.04.003

Stacey, Robert C. (1992). The Conversion of Jews to Christianity in Thirteenth-Century England. Speculum, 67(2), 263-283. https://doi.org/10.2307/2864373

Stich, Stephen (1996). Deconstructing the Mind. Oxford University Press.

Sundstrom, Ronald R. (2002a). Race as a Human Kind. Philosophy E Social Criticism, 28(1), 91-115. https://doi.org/10.1177/0191453702028001592

Sundstrom, Ronald R. (2002b). "Racial” Nominalism. Journal of Social Philosophy, 33(2), 193-210. https://doi.org/10.1111/0047-2786.00133

Suzuki, Lisa and Joshua Aronson (2005). The Cultural Malleability of Intelligence and Its Impact on the Racial/Ethnic Hierarchy. Psychology, Public Policy, and Law, 11(2), 320327. https://doi.org/10.1037/1076-8971.11.2.320

Taylor, Paul C. (2000). Appiah's Uncompleted Argument: WEB Du Bois and the Reality of Race. Social Theory and Practice, 26(1), 103-128. https://doi.org/10.5840/soctheorpract20002616

Taylor, Paul C. (2004). Race: A Philosophical Introduction. Polity.

Templeton, Alan (2013). Biological Races in Humans. Studies in History and Philosophy of Biological and Biomedical Sciences, 44(3), 262-271. https://doi.org/10.1016/j.shpsc.2013.04.010

Thomas, James M. (2010). The Racial Formation of Medieval Jews: A Challenge to the Field. Ethnicand Racial Studies, 33(10), 1737-1755.https://doi.org/10.1080/01419871003706766

Thorleifsdottir, Kristin (2008). Neighborhood Design: Associations Between Suburban Neighborhood Morphology and Children's Outdoor, Out-of-School, Physical Activities. North Carolina State University.

Wagner, Jennifer K., Joon-Ho Yu, Jayne O. Ifekwunigwe, Tanya M. Harrell, Michael J. Bamshad, and Charmaine D. Royal (2016). Anthropologists' Views on Race, Ancestry, and Genetics. American Journal of Physical Anthropology. Advance online publication. doi:10.1002/ajpa.23120

Walsh, Sarah (2015). "One of the Most Uniform Races of the Entire World": Creole Eugenics and the Myth of Chilean Racial Homogeneity. Journal of the History of Biology, 48(4), 613-639. https://doi.org/10.1007/s10739-015-9403-x

Webster, Yehudi O. (1992). The Racialization of America. St. Martin's Press.

Whitaker, Cord J. (2015). Race-ing the Dragon: The Middle Ages, Race and Trippin' into the Future. Postmedieval: A Journal of Medieval Cultural Studies, 6(1), 3-11. https://doi. org/10.1057/pmed.2014.40

Winter, Christine (2015). National Socialism and the German (Mixed-Race) Diasporas in Oceania. In Michael Mann and Nagel G. Jürgen (Eds.), Europa Jenseits Der Grenzen. Festschrift Für Reinhard Wendt (227-251). Draupadi Verlag.

Winther, Rasmus G. (2014). The Genetic Reification Of "Race"?: A Story of Two Mathematical Methods. Critical Philosophy of Race, 2(2), 204-223.

Wolfe, Patrick (2002). Race and Racialisation: Some Thoughts. Postcolonial Studies, 5(1), 51-62. https://doi.org/10.1080/13688790220126889 
Yudell, Michael, Dorothy Roberts, Rob DeSalle, and Sarah Tishkoff (2016). Taking Race out of Human Genetics. Science, 351(6273), 564-565. https://doi.org/10.1126/science. aac4951

Zack, Naomi (2001). Philosophical Aspects of the "AAA Statement on 'Race'". Anthropological Theory, I(4), 445-465. https://doi.org/10.1177/14634990122228836

Zack, Naomi (2002). Philosophy of Science and Race. Routledge. 